\title{
Analysis of arabica coffee productivity due to shading, pruning, and coffee pulp-husk organic fertilizers treatments
}

\author{
Abubakar Karim $^{1}$ (D), Hifnalisa Hifnalisa ${ }^{2}$ (D) Manfarizah Manfarizah² $^{\text {(iD }}$
}

\author{
${ }^{1}$ Aceh Cocoa and Coffee Research Institute, Institute for Research and Community Service, University of Syiah Kuala \\ ${ }^{2}$ Department of Soil Science, Faculty of Agriculture, University of Syiah Kuala \\ Contact authors: karim.abubakar@unsyiah.ac.id; hifnalisa@unsyiah.ac.id; manfarizah@unsyiah.ac.id \\ Received in March 27, 2021 and September 20, 2021
}

\begin{abstract}
Arabica coffee productivity can be increased through improved cultivation techniques. This research aims to analyze Arabica coffee production to treat shading, pruning, and coffee pulp-husk organic fertilizer application. The research was carried out in two stages, in the first stage a field survey was conducted to determine the relatively uniform land and plant characteristics, while in the second stage was the application of coffee pulp-husk organic fertilizer and pruning of shaded and non-shaded coffee plants by using farmer's method and the recommended methods by the authors. The application of coffee pulp-husk organic fertilizer consists of $0,2.50,5.00$, and $7.50 \mathrm{~kg} \mathrm{tree}^{-1}$, which is equivalent to $0,4,8$, and 12 tons ha-1 respectively. This research was arranged in a split-plot design, with shades placed in the main plot, while pruning and the application of coffee pulp-husk organic fertilizer in the subplots. The variables observed were the number of redcherries tree ${ }^{-1}$, greenbean (dry bean) production, and rendement (yield) production at $14 \%$ moisture content. Furthermore, the best effect and treatment were determined using variance analysis and the least significant difference (LSD). The result showed that shade only affected rendement production at $14 \%$ moisture content, coffee with shade is better than no shade, pruning affected the number of redcherries and greenbean production. Furthermore, the recommended pruning was better than farmer pruning, while coffee pulp-husk organic fertilizer affected all observed variables. Therefore, the best dose is $7.50 \mathrm{~kg}^{-1}$ tree $^{-1}\left(12\right.$ ton $\mathrm{ha}^{-1}$ ) because the treatment combination (SxPxF) affected only greenbean production.
\end{abstract}

Key words: People's coffee garden; Redcherries; Yield bean; Dry greenbean.

\section{INTRODUCTION}

Arabica coffee productivity is enhanced by improving cultivation techniques, such as sowing various cultivars, land suitability, plant, maintenance, shade, pruning, and fertilization. Light is also an essential environmental resource that tends to affect photosynthesis and plant growth. Valladares et al. (2000) reported that its limitation resulted in plant adaptation. The use of various types of shade trees and cultivation techniques affects coffee growth, production, and quality. According to Alemu (2015), shade trees are needed to protect coffee plants from excessive sunlight and extend the plants' economic life. Erdiansyah and Yusianto (2012), stated that their response to shades is extremely diverse and largely influenced by soil fertility, local climate, and species cultivation.

Sun-grown coffee results in the development of excess flowers, and a balanced carbohydrate production is needed to maintain the fruit load (Da Matta, 2004). On the contrary, Vaast et al. (2006) reported that shade reduces coffee productivity by $18 \%$. However, it has a positive impact on the bean's size, composition, and quality by delaying the ripe pulp for relatively a month (Vaast et al., 2006). In the Gayo Highlands, the commonly used shade for coffee plants is leguminous trees, such as lamtoro. Shade trees play an important role based on their function as a coffee plantation ecosystem (Evizal et al., 2010; Vaast et al., 2005). They produce litters, reduce soil and leaf temperatures, thereby sustaining a regular level, reduces leaf loss during the dry season, suppresses weed growth and erosion (Khasanah; Farida; van Noordwijk, 2004), produces organic matter (Beer, 1988), as well as increases coffee flowering (Lin, 2008).

Shade-grown coffee produces high-yields than those cultivated directly under the sun (Evizal et al., 2012). The shedding of litters is significant because it replaces the loss of nutrients (particularly nitrogen) during the coffee fruit harvest. It is speculated that the increase in certain soil minerals and nutrients is related to the type of shade (Erwiyono; Prawoto, 008). Coffee plants grown in the shade yield higher yields than those grown in the sun (Somporn et al., 2012; Alemu, 2015; Lisnawati et al., 2017; Piato et al., 2020), in addition, the Gayo Highlands, particularly the Pantan Cuaca Sub District, generally uses lamtoro (Hifnalisa; Karim, 2008; Izzati et al., 2019). Traditional farmers in Mexico and Costa Rica plant non-leguminous shades, including fruit trees, timber, and other fuelwood crops (Peeters et al., 2003; Schaller et al., 2003).

Pruning is one of the most important cultivation techniques applied during coffee farming because it aids in the proper development of the branches which bear the fruits. However, the growth of coffee plants is largely determined by the number of productive branches during fertilization. Generally, pruning is routinely and adequately carried out in various Arabica coffee producing countries. For example, in India, it is always pruned to keep the plants short and easy to harvest. Likewise, in Vietnam, Robusta coffee is pruned 
to expose plagiotropic branches above the plant, while the productive ones lean downward, thereby shaped like an open umbrella (Cunha et al., 2011). This cultivation technique is an effective solution that aids to reduce the effect of excessive initial constriction in Arabica coffee plantations. It is associated with high-yields due to the advancement of reproductive output in different plant species (Bilir et al., 2006; Dutkuner; Bilir; Ulusan, 2008).

Some species respond differently to pruning in terms of growth rates and patterns however, due to the diverse canopies, they are necessary to carry out a study on the adaptation capacity and characterization of cultivar, including recommended cultivation techniques (Rodrigues et al., 2017). Also, pruning and fertilization reduce the negative effects of shade-grown coffee plants. They also help farmers improve their plantations sustainability by producing larger and quality beans (Vaast et al., 2006).

The application of organic materials is an annual fertilization program. Subsequently, organic fertilizers are obtained from the plantation or produced by the farmer. According to Erwiyono and Prawoto (2008), fertilized plants are also resistant to pests and diseases. Karim, Sudarsono, and Anas (1999a), reported that fertilization is related to the various needs of plants as well as the sustainability of the soil quality, particularly the topsoil.

The vegetative growth of plants, such as the development of fruit-bearing branches, tends to be hampered or even stopped in the subsequent year due to nutrient deficiency. This hampered the production capacity of the coffee plants, thereby resulting in small-sized beans and low-yields. Furthermore, the yearly fluctuation in production tends to be more intense as a result of nutrient deficiency (Karim; Sudarsono; Anas, 1999a). Moreover, it was stated that Arabica coffee plants are known to thrive in soils with high organic matter content, and it is directly related to its productivity. The optimal organic matter content for coffee plants ranges from 2 to $5 \%$, depending on the class of soil texture class. Therefore, it plays an important role in productivity because it influences the soil's physical, chemical, and biological characteristics.

Furthermore, it is also related to air in the soil and organisms, water infiltration, as well as suppresses erosion (Khasanah; Farida; van Noordwijk, 2004). The level of organic matter in the soil needs to be conserved and improved by good cultivation practices. It is important to protect the soil with shade trees, cover crops, and organic mulch. Consequently, approximately 10 to $15 \mathrm{~kg}$ of manure needs to be added at the beginning of the rainy season. In addition, it needs to be covered with a little topsoil or straw and must not touch the stem because it damages the coffee tree (Beer, 1988). This study aims to analyze Arabica coffee's productivity affected by the treatments of shades, pruning, and application of coffee pulp-husk organic fertilizers.

\section{MATERIAL AND METHODS}

This research was carried out in Pantan Cuaca SubDistrict, Gayo Lues District, Aceh from March 2018 to October 2020, and is expected to be observed till the third year of treatment.

The materials used are Arabica coffee plantations owned by farmers in the region. The plantation criteria, includes genotype G1, aged 15-20 years, a medium density lamtoro shade (approximately 225 to 250 tree ha $^{-1}$ ) sun-grown, located at an altitude of relatively 1,200 to $1,400 \mathrm{~m}$ asl, slope of about 15 to $25 \%$, lack of fertilization and pruning schedule which is only carried out when needed. Furthermore, the plantation is weed control when necessary, irrespective of the fact that it lacks control of pests and diseases.

The object of research is coffee plantations that meet the relatively uniform criteria in the field. The study was carried out in two stages, namely:

1. Agroecosystem survey of Arabica coffee. The survey characteristics include G1 genotype, aged 15 to 20 years, altitude relatively 1,200 to $1,400 \mathrm{~m}$ asl, slopes approximately 15 to $25 \%$, and farmers' management. Furthermore, information concerning cultivation techniques observed in the field included fertilization, the presence and absence of shade trees, pruning, as well as pest and disease control. Coffee farmers in this area only use lamtoro (Leucaena sp.) shade, pruning, and pest and disease control. Production data obtained from field surveys with direct observation. There are 3 sample trees used to observe the production of each specified sub-location.

2. Field experiments were carried out on Arabica coffee plantations with genotype $\mathrm{G} 1$ aged 15 to 20 years, at an altitude of approximately 1,200 to $1,400 \mathrm{~m}$ asl, slopes of relatively 15 to $25 \%$, and the presence and absence of shades (according to criteria number 1)

This research was carried out using a split-plot design, based on the experimentation of 3 factors, namely:

a. Shade trees encompassing of lamtoro (Leucaena $\mathrm{Sp}$.) species as the main plot, ie absence of shade $\left(\mathrm{S}_{0}\right)$ and its presence $\left(\mathrm{S}_{1}\right)$. Some of the coffee plantations that are cultivated by farmers in this area are shaded and some are not shaded. For coffee plantations that have shade, in general, coffee farmers in this area only use the shade of the lamtoro type with a spacing of 7 m x 6 m (238 trees ha-1).

b. Pruning as sub-plots, namely pruning based on the farmer's method $\left(\mathrm{P}_{1}\right)$ and pruning in accordance with recommendations $\left(\mathrm{P}_{2}\right)$. Farmer pruning methods are described: trim the shape (toping), trim the wiwilan (shoots below the base of the branch) when needed (unscheduled). Pruning recommendations are described: aimed at increasing production by pruning shape, pruning wiwilan, pruning unproductive branches and pruning maintenance. All of these pruning methods are carried out 3-4 times a year. 
c. Providing organic fertilizer from coffee pulp and husk (hereinafter referred to as coffee pulp-husk organic fertilizers) as subplots, namely its absence $\left(\mathrm{F}_{0}\right)$, and its presence at a dose of $2.50 \mathrm{~kg}$ tree $^{-1}\left(\mathrm{~F}_{1}\right), 5.00 \mathrm{~kg}$ tree $^{-1}\left(\mathrm{~F}_{2}\right)$, and $7.50 \mathrm{~kg}$ tree$^{-1}\left(\mathrm{~F}_{3}\right)$. Coffee pulp-husk organic fertilizer is applied twice a year, in March and September every year.

The treatment combination was obtained at $2 \times 2 \times$ $4=16$ experimental units, which was subsequently referred to as the site, and this was replications 3 times for each of them, thereby obtaining 48 units referred to as the subsite. Furthermore, 3 coffee trees were used to define the treatment sites and each of the sub-sites, leading to a total of 144 sample coffee trees.

The variables observed were the number of cherries coffee tree ${ }^{-1}$, greenbean production of Arabica coffee, greenbean rendement $14 \%$ moisture content. This variable was observed for two years, namely 2019 and 2020, after being treated in 2018. The data in this article used production data in the large harvest months for the period September December 2020. The data were then analyzed based on the variance (ANOVA) tests in the $\mathrm{F}_{0.05}$ and $\mathrm{F}_{0.01}$, including the Least Significance Different $\left(\mathrm{LSD}_{0.05}\right)$ test for those variables that were significantly affected.

The number of cherries coffee tree $e^{-1}$ was obtained by directly counting each sample coffee tree (taxation) for each treatment and replication. The number of sample trees for production observations of each sub-site that meets the criteria is 3 trees. The number of cherries coffee per hectare is calculated based on the average number of coffee cherries tree ${ }^{-1}$ (taxation result) multiplied by the number of trees ha-1 ${ }^{-1}(1,600$ trees) (a). The coffee greenbean production per hectare is calculated by harvesting $2 \mathrm{~kg}$ of redcherries from the sample plant. The next step involves counting the number of redcherries before milling (b). The redcherries from $2 \mathrm{~kg}$ of redcherries is milled, fermented, peeled, and dried under the sun to obtain $14 \%$ moisture content, which was subsequently weighed (c). Coffee greenbean production per hectare: [(a) / (b)] x (c), the yield is the percentage of greenbean with a moisture content of $14 \%$ to the total weight of coffee red cherries per hectare.

\section{RESULTS}

The recapitulation of the ANOVA results is based on the observation of the following variables, the number of redcherries tree ${ }^{-1}$, greenbean production, and rendement at $14 \%$ moisture content, genotype G1 Arabica coffee in accordance with the treatment procedures, namely shades, pruning, and application of coffee pulp-husk organic fertilizer is shown in Table 1.

Table 1 shows that the presence of shade has a significant on Arabica coffee greenbean productions, pruning has a significant on the number of cherries coffee per tree and Arabica coffee greenbean production, coffee pul-husk organic fertilizer treatment has a significant on the number of cherries coffee per tree, greenbean production, and greenbean rendement on $14 \%$ water content.

Table 1: Recapitulation of ANOVA Results on all Variables Observed in Genotype G1 Arabica Coffee due to the Treatment of Shades, Pruning, and the Application of Coffee Pulp-Husk Organic Fertilizer.

\begin{tabular}{|c|c|c|c|}
\hline Treatment & $\begin{array}{c}\text { Number of } \\
\text { Redcherry trees }^{-1}\end{array}$ & $\begin{array}{l}\text { Greenbean } \\
\text { Production }\end{array}$ & $\begin{array}{c}\text { Rendement at } 14 \% \\
\text { Moisture Content }\end{array}$ \\
\hline $\mathrm{S}$ & ns & ns & $* *$ \\
\hline $\mathrm{P}$ & $*$ & $* *$ & ns \\
\hline $\mathrm{F}$ & $* *$ & $* *$ & $* *$ \\
\hline $\mathrm{S} \times \mathrm{P}$ & ns & Ns & ns \\
\hline $\mathrm{S} \times \mathrm{F}$ & ns & Ns & ns \\
\hline $\mathrm{P} \times \mathrm{F}$ & ns & Ns & ns \\
\hline$S \times P \times F$ & ns & * & ns \\
\hline
\end{tabular}

Description: $\mathrm{S}=$ shade, $\mathrm{P}=$ pruning, $\mathrm{F}=$ application of coffee pulp-husk organic fertilizer, ${ }^{*}=$ significant on $\mathrm{F}_{0,05},{ }^{* *}=$ hightly significant on $\mathrm{F}_{0,01}$, ns $=$ no insignificant.

The data obtained from the average greenbean rendement at a moisture content of $14 \%$ under the shade treatment and average numbers of cherries coffee tree ${ }^{-1}$, including the greenbean production due to pruning in genotype G1 Arabica coffee, are shown in Table 2.

Table 2: Average Greenbean Rendement at Moisture Content of $14 \%$ under the Shade Treatment and Average Number of Redcherries tree ${ }^{-1}$ as well as the Production of greenbean due to Pruning in Arabica Coffee, Genotype G1.

\begin{tabular}{ccccc}
\hline Treatment & GR14\% & Treatment & NRT & GP \\
\hline $\mathrm{S}_{0}$ & $20.81 \mathrm{a}$ & $\mathrm{P}_{1}$ & $20.00 \mathrm{a}$ & $1.197 .88 \mathrm{a}$ \\
$\mathrm{S}_{1}$ & $23.62 \mathrm{~b}$ & $\mathrm{P}_{2}$ & $21.67 \mathrm{~b}$ & $1.417 .00 \mathrm{~b}$ \\
LSD $_{0.05}$ & 0.24 & LSD $_{0,05}$ & 1.45 & 35.30 \\
\hline
\end{tabular}

Description: The number followed by a different lowercase letter in one column shows that it is significantly different in the LSD test of 0.05 . $\mathrm{S}_{0}=$ no shade, $\mathrm{S}_{1}=$ Lamtoro shade; $\mathrm{GR} 14 \%$ = greenbean rendement at $14 \%$ moisture content $(\%)$; NRT $=$ number of redcherries per tree (cherries); GP = greenbean (dry bean) production $\left(\mathrm{kg} \mathrm{ha}^{-1}\right) ; \mathrm{P}_{1}=$ pruning based on the farmer's method, $P_{2}=$ pruning in accordance with recommended methods by the authors.

Table 2 shows that shaded and unshaded coffee plantations were significantly different from greenbean rendement at $14 \%$ moisture content. Likewise, the pruning of recommendations was significantly different from the pruning of farmers on the variables of the number of fruits per tree and Arabica coffee greenbean production. 
The data on the average number of redcherries per tree, greenbean production, and greenbean rendement at $14 \%$ moisture content due to coffee pulp-husk organic fertilizer treatment shown in Table 3.

Table 3: Average Number of Redcherries per Tree ${ }^{-1}$, Greenbean Production and Greenbean Rendement at 14\% Moisture Content due to Application of Coffee Pulp-Husk Organic Fertilizer to Arabica Coffee Genotype G1.

\begin{tabular}{cccc}
\hline Treatment & $\begin{array}{c}\text { Number of } \\
\text { Redcherries tree } \\
(\text { Cherry })\end{array}$ & $\begin{array}{c}\text { Greenbean } \\
\text { Productionn } \\
\left(\mathrm{kg} \mathrm{ha}^{-1}\right)\end{array}$ & $\begin{array}{c}\text { Greenbean } \\
\text { Rendement } \\
\text { of } 14 \% \text { Moisture } \\
\text { Content }(\%)\end{array}$ \\
\hline $\mathrm{F}_{0}$ & $1.174 .25 \mathrm{a}$ & $1.141 .42 \mathrm{a}$ & $20.76 \mathrm{a}$ \\
$\mathrm{F}_{1}$ & $1.257 .42 \mathrm{ab}$ & $1.204 .67 \mathrm{a}$ & $21.85 \mathrm{ab}$ \\
$\mathrm{F}_{2}$ & $1.303 .00 \mathrm{~b}$ & $1.424 .67 \mathrm{~b}$ & $22.60 \mathrm{bc}$ \\
$\mathrm{F}_{3}$ & $1.352 .67 \mathrm{~b}$ & $1.459 .00 \mathrm{~b}$ & $23.63 \mathrm{c}$ \\
$\mathrm{LSD}_{0,05}$ & 101.56 & 138.89 & 1.70 \\
\hline
\end{tabular}

Description: The number followed by a different lowercase letter in one column shows significantly different in the LSD test of 0.05. Application of coffee pulp-husk organic fertilizer; absence $\left(F_{0}\right), 2.50 \mathrm{~kg}^{-1}$ tree $^{-1}\left(F_{1}\right)$, $5.00 \mathrm{~kg} \mathrm{tree}^{-1}\left(\mathrm{~F}_{2}\right)$, and $7.50 \mathrm{~kg} \mathrm{tree}^{-1}\left(\mathrm{~F}_{3}\right)$.

Table 3 shows that the application of coffee pulp-husk organic fertilizer with various doses was significantly different from that of no coffee pulp-husk organic fertilizer on the number of coffee cherries per tree, greenbean production, and greenbean rendement at $14 \%$ moisture content. However, the application of organic fertilizer at doses of 8 and 12 tons/ha did not differ significantly with each other on the variable number of coffee cherries per tree, greenbean production, and rendement at $14 \%$ moisture content. The trend of variables in the number of redcherries, greenbeans production, and greenbean rendement at a level of $14 \%$ is presented in Figure 1.

Data on the average greenbean production of Arabica coffee genotype G1 are presented in Table 4. Greenbean production and greenbean rendement at $14 \%$ water content were the highest in the treatment of coffee plants with shade, recommendation pruning, and $7.50 \mathrm{~kg}^{\text {tree }}{ }^{-1}$ (12 ton $\left.\mathrm{ha}^{-1}\right)$ coffee pulp-husk organic fertilizer $\left(\mathrm{S}_{1} \mathrm{P}_{2} \mathrm{~F}_{3}\right)$. Although this combination was not significantly different from the combination of $\mathrm{S}_{1} \mathrm{P}_{2} \mathrm{~F}_{2}$ and $\mathrm{S}_{1} \mathrm{P}_{2} \mathrm{~F}_{1}$.

\section{DISCUSSION}

Table 1 shows that shade only had a significant effect on greenbean rendement at $14 \%$ moisture content. Pruning affected the number of redcherries per tree and greenbean production, however the greenbean rendemen at $14 \%$ moisture content was unaffected. This is inconsistent with the study carried out by Siahaan (2020) in Humbang Hasunudan, North

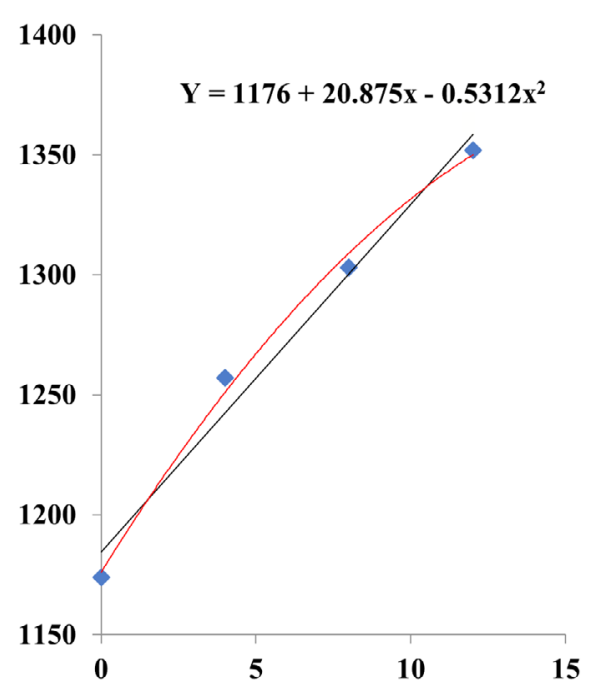

Treatments organic fertilizer (ton ha'
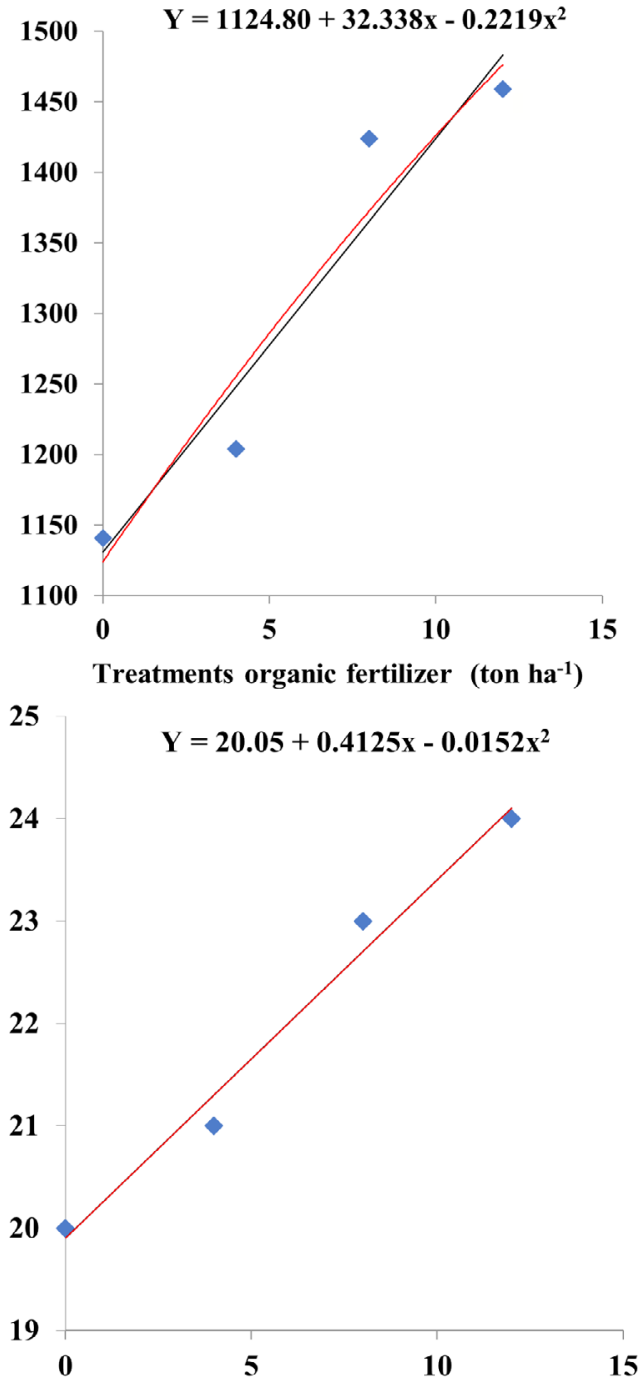

Treatments organic fertilizer (ton ha-1)

Figure 1: Performance of the Number of redcherries (a), green bean production (b), and greenbean rendement at a moisture content of $14 \%$ (c) due to the application of various doses of coffee pulp-husk organic fertilizer. 
Sumatra, which stated that pruning does not affect production. In addition, the application of organic coffee pulp-husk fertilizer affected all the variables. The combination of the three treatments $(\mathrm{SxPxF})$ only had a significant effect on the production of greebean coffee. However, a combination of SxP, SxF, and PxF has an insignificant effect on all variables.

Table 4: Average Greenbeans Production due to Combination of Shade, Pruning, and Application of Coffee Pulp-Husk Organic Fertilizer on Arabica Coffee Genotype G1.

\begin{tabular}{ccc}
\hline Treatment & $\begin{array}{c}\text { Greenbean Production } \\
\left(\mathrm{kg} \mathrm{ha}^{-1}\right)\end{array}$ & $\begin{array}{c}\text { Percentage of Normal } \\
\text { Beans }(\%)\end{array}$ \\
\hline $\mathrm{S}_{0} \mathrm{P}_{1} \mathrm{~F}_{0}$ & $1.048 .33 \mathrm{a}$ & $86.86 \mathrm{a}$ \\
$\mathrm{S}_{0} \mathrm{P}_{1} \mathrm{~F}_{1}$ & $1.030 .67 \mathrm{a}$ & $87.74 \mathrm{a}$ \\
$\mathrm{S}_{0} \mathrm{P}_{1} \mathrm{~F} 2$ & $1.098 .33 \mathrm{ab}$ & $87.96 \mathrm{a}$ \\
$\mathrm{S}_{0} \mathrm{P}_{1} \mathrm{~F}_{3}$ & $1.137 .33 \mathrm{ab}$ & $87.59 \mathrm{a}$ \\
$\mathrm{S}_{0} \mathrm{P}_{2} \mathrm{~F}_{0}$ & $1.111 .33 \mathrm{ab}$ & $89.12 \mathrm{a}$ \\
$\mathrm{S}_{0} \mathrm{P}_{2} \mathrm{~F}_{1}$ & $1.099 .33 \mathrm{a}$ & $87.25 \mathrm{a}$ \\
$\mathrm{S}_{0} \mathrm{P}_{2} \mathrm{~F}_{2}$ & $1.539 .33 \mathrm{~b}$ & $90.04 \mathrm{~b}$ \\
$\mathrm{~S}_{0} \mathrm{P}_{2} \mathrm{~F}_{3}$ & $1.553,67 \mathrm{~b}$ & $89.56 \mathrm{~b}$ \\
$\mathrm{~S}_{1} \mathrm{P}_{1} \mathrm{~F}_{0}$ & $1.036 .67 \mathrm{a}$ & $89.46 \mathrm{ab}$ \\
$\mathrm{S}_{1} \mathrm{P}_{1} \mathrm{~F}_{1}$ & $1.176 .00 \mathrm{ab}$ & $88.79 \mathrm{a}$ \\
$\mathrm{S}_{1} \mathrm{P}_{1} \mathrm{~F}_{2}$ & $1.569 .33 \mathrm{~b}$ & $89.44 \mathrm{ab}$ \\
$\mathrm{S}_{1} \mathrm{P}_{1} \mathrm{~F}_{3}$ & $1.486 .33 \mathrm{~cd}$ & $91.06 \mathrm{~b}$ \\
$\mathrm{~S}_{1} \mathrm{P}_{2} \mathrm{~F}_{0}$ & $1.369 .33 \mathrm{bc}$ & $88.19 \mathrm{a}$ \\
$\mathrm{S}_{1} \mathrm{P}_{2} \mathrm{~F}_{1}$ & $1.512 .67 \mathrm{~cd}$ & $90.41 \mathrm{bc}$ \\
$\mathrm{S}_{1} \mathrm{P}_{2} \mathrm{~F}_{2}$ & $1.491 .67 \mathrm{~cd}$ & $89.86 \mathrm{ab}$ \\
$\mathrm{S}_{1} \mathrm{P}_{2} \mathrm{~F}_{3}$ & $1.658 .67 \mathrm{~d}$ & $91.91 \mathrm{c}$ \\
$\mathrm{LSD}_{0}$ & 277.70 & 1.95 \\
\hline
\end{tabular}

Description: The number followed by a different lowercase letter in one column shows that it is not significantly different in the LSD test of $0.05 . S_{0}=$ no shade, $S_{1}=$ Lamtoro shade; $P_{1}=$ pruning based on the farmer's method, $P_{2}=$ pruning in accordance with recommendations. Application of coffee pulp-husk organic fertilizer; absence $\left(F_{0}\right), 2.50 \mathrm{~kg}$ tree $^{-1}\left(F_{1}\right), 5.00 \mathrm{~kg}$ tree-1 $\left(F_{2}\right)$, and $7.50 \mathrm{~kg}$ tree $^{-1}\left(F_{3}\right)$.

Table 2 shows that a significant difference was detected in greenbean rendement at $14 \%$ moisture content cultivated with shade and without shade. Coffee plants require high intensity of sunlight, but not directly, therefore coffee plants need shade in their growth and development (Siahaan, 2020). That is, the coffee plant produces excess flowers when cultivated not in the shade and. including several locations in Central Aceh and Bener Meriah District and Gayo Lues, Aceh Province (Karim; Wiradisastra; Sudarsono, 1999b). It is possible that the shade causes the atmosphere of the coffee garden to be cooler than one maintained without shade (Sobari; Sakiroh; Purwanto, 2012). This condition is in line with the results of previous research, that Arabica coffee is grown at higher altitudes in Central Aceh, Bener Meriah District (Wahyuni; Karim; Anhar,
2013) and in Gayo Lues Regency (Izzati et al., 2019), the lower the temperature.-Shade trees play an important role as a coffee plantation agroecosystem (Evizal et al., 2010; Vaast et al., 2005). Shade trees can contribute to litter, suppress weed growth, suppress erosion, and in the dry season can reduce coffee leaf loss (Khasanah; Farida; van Noordwijk, 2004; Muschler, 2001), produces organic matter (Beer, 1988), and enhances flowering (Lin, 2008). Furthermore, they reduce soil and leaf temperatures as well as maintains a regular level of temperature (Muschler, 2001; Khasanah; Farida; van Noordwijk, 2004).

Although shade-grown coffee plants improve the agroecosystem, they only increase their production insignificantly. These findings are consistent with Cerda et al. (2017), which reported that in Costa Rica, shade-grown coffee plants in agroforestry have an insignificant effect on their production. However, it was discovered that coffee production under shaded conditions was more stable over a long period. This study's results are inconsistent with the research carried out by Siles, Harmand and Vaast (2010), which stated that shade plays a vital role in enhancing coffee productivity in the intercropping system.

The data on the average number of fruits per tree and dry bean production due to pruning treatment in genotype G1 Arabica coffee is shown in Table 2. Furthermore, several pruning types were adopted in this study, and they are intended for production and maintenance. Coffee plants need to be pruned in order to increase the number of productive branches, redcherries per trees, greenbean production per hectare, and greenbean rendement. Pruning stimulated the translocation of nutrients to the productive branches, thereby harvesting a perfect cherry. Pruning stimulates the translocation of nutrients to productive branches, thereby harvesting the perfect redcherry. Furthermore, the number of redcherries per tree, greenbean production per hectare, and greenbean rendement at $14 \%$ moisture content increased. In Vietnam, coffee plants are pruned to develop plagiotropic branches exposed at the top, and the productive ones are leaning downward, thereby having an open umbrella-like shape (Bilir et al., 2006). The irregular and extremely narrow rows in coffee spacing cause the canopies to overlap as the plant develops (Arvi; Syakur; Karim, 2019; Izzati et al., 2019). Pruning is an effective solution that reduces the effect of constriction in the coffee plantation agroecosystem. It is a technology associated with extremely high yields due to reproductive output (Dutkuner; Bilir; Ulusan, 2008).

Pruning is intended for the development of productive branches such as coffee fruit producers. The productivity of coffee plants is determined by the number of fruits on the branches during each fertilization season (Arvi; Syakur; Karim, 2019; Izzati et al., 2019). Authors' experience in managing coffee plantations, continuous direct and continue 
sunlight led to the massive growth of flowers. These flowers have the opportunity to develop into fruits, but they lack of the quality, such as more floating fruit and smaller bean in sizes (Karim; Sudarsono; Anas, 1999a; Da Matta, 2004; Evizal et al., 2010; Cerda et al., 2017). This occurs due to the competition for carbohydrates in the fruit filling period. Consequently, this condition that involves pruning needs to be balanced to increase the coffee plantation agroecosystem's sustainability and produce relatively larger sized coffee beans with extremely high quality (Vaast et al., 2006).

Table 3 shows the number of fruits per tree, dry bean production, and yield at $14 \%$ moisture content of Arabica coffee genotype G1 look better and is significantly different from the application of organic coffee skin fertilizer applied at a higher dose of relatively $7.50 \mathrm{~kg} \operatorname{tree}^{-1}\left(12\right.$ ton ha $\left.{ }^{-1}\right)$. Generally, it is evident that all variables increase with fertilizer application at $7.50 \mathrm{~kg}$ per tree. This simply implies that the application of this type of fertilizer shows positive results, thereby improving coffee production.

The application of $7.50 \mathrm{~kg}$ of organic fertilizer per tree resulted in a bean production of $1,658.67 \mathrm{~kg} \mathrm{ha}^{-1}$ while its yield at $14 \%$ moisture content was $23.63 \%$. This means that each hectare of coffee plantation managed organically produces 4-5 ton of coffee pulp-husk. This figure is obtained based on calculations; $\left(100 / 23.63 \times 1,658,67 \mathrm{~kg} \mathrm{ha}^{-1}\right)-1,658.67 \mathrm{~kg} / \mathrm{ha}$ $=5,360.67 \mathrm{~kg} \mathrm{ha}^{-1}$. The results from this calculation is slightly different from the findings of Karim, Sudarsono and Anas (1999a), which stated that every hectare of coffee plantation managed organically in Central Aceh produces relatively 5 to 6 ton of coffee pulp-husk. Furthermore, it was stated that coffee skin contained $\mathrm{N}, \mathrm{P}, \mathrm{K}, \mathrm{Ca}, \mathrm{Mg}$, ash content, and $\mathrm{pH}$ of $2.23 \%, 0.19 \%, 1.89 \%, 0.15 \%, 0.01 \%, 38.30 \%$, and 6.05 , respectively. Based on this study, the application of $7.50 \mathrm{~kg}$ (12 ton $\mathrm{ha}^{-1}$ ) of organic coffee pulp-husk fertilizer per tree means that the application of $\mathrm{N}, \mathrm{P}, \mathrm{K}, \mathrm{Ca}$, and $\mathrm{Mg}$ is 267.60 $\mathrm{kg} \mathrm{ha}^{-1}$ (approximately $600 \mathrm{~kg}$ of Urea), $22.80 \mathrm{~kg} \mathrm{ha}^{-1}(63.33$ $\mathrm{kg}$ phosfat fertilizer), $226.80 \mathrm{~kg} \mathrm{ha}^{-1}(378 \mathrm{~kg} \mathrm{KCl}), 18.00 \mathrm{~kg}$ $\mathrm{ha}^{-1}\left(45 \mathrm{~kg} \mathrm{CaCO}_{3}\right)$, and $1.20 \mathrm{~kg} \mathrm{ha}^{-1}(2 \mathrm{~kg} \mathrm{MgO})$ respectively. Therefore, the nutrient distribution is relatively sufficient to produce coffee beans of approximately 1-2 ton ha- ${ }^{-1}$, except for P nutrients. Apart from the coffee plantation, agro-ecosystems that are properly managed under the shade of lamtoro, produce relatively 6 to 8 ton/ha of organic fertilizer for pruning and approximately 4 to 6 ton ha ${ }^{-1}$ of weeds (about 3 to 4 times yearly) (Karim; Wiradisastra; Sudarsono; 1999b).

The application of organic matter from any source not only prioritizes the contribution of nutrients, but more than that, it also improves the physical properties of the soil, such as causing it to become loose, improved aeration, and microbial activities to produce nutrients for the coffee plants. It is assumed that the nutrient contribution and improvement of soil properties lead to the application of excessive organic fertilizers to obtain better growth, productivity, and the coffee's physical quality. The high $\mathrm{C}$-organic in soil could be increased the soil $\mathrm{pH}, \mathrm{CEC}$ and base saturation such as $\mathrm{Ca}, \mathrm{K}, \mathrm{Mg}, \mathrm{Na}$ with the result that the nutrients absorbed in soil colloids can available for plants (Marbun et al., 2020).

Table 4 shows that the highest greenbean production was obtained in the $\mathrm{S}_{1} \mathrm{P}_{2} \mathrm{~F}_{3}$ treatment, but it was not significantly different from the $\mathrm{S}_{1} \mathrm{P}_{2} \mathrm{~F}_{2}$ and $\mathrm{S}_{1} \mathrm{P}_{2} \mathrm{~F}_{1}$ treatments. The combination of the presence of shade, recommendation pruning, and coffee pulp-husks organic fertilizer for of 7.50 $\mathrm{kg}$ tree $^{-1}\left(12\right.$ ton $\left.\mathrm{ha}^{-1}\right)$ resulted in greenbean production of $1,658.67 \mathrm{~kg} \mathrm{ha}^{-1}$.

Generally, shade-grown coffee plantations, both authors' recommendation and farmers' pruning method, including a $5.00 \mathrm{~kg} \operatorname{tree}^{-1}$ (8 tons/ha) or $7.50 \mathrm{~kg}^{\text {tree }}$ (12 $^{-1}$ ton $\mathrm{ha}^{-1}$ ) of coffee pulp-husk organic fertilizer, provides the highest greenbean bean production, which is significantly different from other treatments. This condition illustrated that the shade affects coffee plantations' microclimate, particularly by reducing the temperature to the optimal range. Sun-grown coffee plants boost the absorption of carbohydrates from the leaves and stem from accelerating fruits and flowers' formation. Muschler (2001) reported that the shade slows down coffee cherries's ripening and produces larger beans with better physical quality. According to Prawoto (2008), shade-grown Robusta coffee produces larger beans (diameter $\geq 7.5 \mathrm{~m}^{-3}$ ) than those cultivated in its absence. Coffee plants cultivated with shade $\left(\mathrm{S}_{1}\right)$, recommended pruning $\left(\mathrm{P}_{2}\right)$, and 7.50 $\mathrm{kg}$ tree $^{-1}\left(\mathrm{O}_{3}\right)$ of coffee pulp-husk organic fertilizers $\left(\mathrm{F}_{3}\right)$ were used to obtain the best results, which was significantly different from the other treatments. Table 4 shows that this treatment combination $\left(\mathrm{S}_{1} \mathrm{P}_{2} \mathrm{~F}_{3}\right)$ can be increase greenbean production by more than $50 \%$ compared to the $\mathrm{S}_{0} \mathrm{P}_{1} \mathrm{~F}_{0}$ treatment combination.

The mixture of coffee production with compost material was reported to be higher than without composts material (Piato et al., 2021). This study found that the application of organic fertilizer at 7.50 tons per hectare can increase coffee production by $22 \%$, the number of coffee cherries per tree by $15 \%$, and $14 \%$ water content yield by $13 \%$ (Table 3 ).

The application of coffee pulp-husk organic fertilizer also improves the physical properties of the soil. Primarily, it aids in maintaining soil balance, and the effectiveness and efficiency of nutrients absorption, increasing $\mathrm{pH}$, and improving the ability to retain water (Karim; Sudarsono; Anas, 1999a). Furthermore, it was reported that compost provides both macro and micronutrients for plants, improves soil productivity and fertility, improves aeration and drainage, increases the binding force between particles and the capacity to retain water thereby reducing the leaching of dissolved nitrogen, as well as enhances cultivation. In addition, compost aids in sustaining the soil by ensuring the nutrients are easily absorbed by plants. 


\section{CONCLUSIONS}

Shade, pruning, and application of coffee pulp-husk organic fertilizer affect the Arabica coffee production and components production. The coffee plants were shaded with lamtoro (Leucaena sp.), pruned according to the recommendations, and application of coffee pulp-husk organic fertilizer as much as $7.50 \mathrm{~kg}$ tree $^{-1}\left(12\right.$ ton $\left.\mathrm{ha}^{-1}\right)$ was the best treatment.

Based on the results of this study, it is recommended that the G1 genotype Arabica coffee cultivation in Gayo Lues District should use shade, recommendation pruning (pruning maintenance and production), and applications coffee pulphusk organic fertilizers at 5.00-7.50 kg tree ${ }^{-1}$ (8-12 tons ha-1).

\section{ACKNOWLEDGMENTS}

This research was supported by the Syiah Kuala University Research and Community Service Center in 20192020. Therefore, it is appropriate to convey thanks to the chairperson of the Institute for Research and Community Service, University of Syiah Kuala. Thanks are also conveyed to the parties who have helped the smooth running of this research.

\section{REFERENCES}

ALEMU, M. M. Effect of tree shade on coffee crop production. Journal of Sustainable Development, 8(9):66-70, 2015.

ARVI, D.; SYAKUR, S.; KARIM, A. The elevation relation and slope toward Gayo 1 Arabica coffee production in Gayo Lues. Jurnal Ilmiah Mahasiswa Pertanian, 4(4):596-602, 2019.

BEER, J. Litter production and nutrient cyclingin coffee (Coffeaarabica) or cacao (Theobroma cacao) plantations withshade trees. Agroforestry Systems, 7:103-114, 1988.

BILIR, N. et al. Growth characters and number of strobili in clonal seed orchards of Pinus sylvestris. Euphytica, 152:1-9, 2006.

CERDA. R. et al. Effects of shade, altitude and management on multiple ecosystem services in coffee agroecosystems. European Journal of Agronomy, 82:308-319, 2017.

CUNHA, R. L et al. Pruning management in coffee plants. In: REIS, P. R.; CUNHA, R. L. Arabica coffee: From sowing to harvest. Lavras, Epamig (in Portuguese). 2011.

DA MATTA, F. M. Ecophysiological constraints on the production of shaded and unshaded coffee: A review. Field Crops Research, 86(2-3):99-114, 2004.
DUTKUNER, I.; BILIR, M.; ULUSAN, M. D. Influence of growth on reproductive traits and its effect on fertility and gene diversity in a clonal seed orchard of scots pine, Pinus Sylvestris L. Journal of Environmental Biology, 29(3):349-352, 2008.

ERDIANSYAH, N. P.; YUSIANTO, D. Relationship between caffeine content and flavor with light intensity of several coffee Robusta clones. Pelita Perkebunan, 28(1):14-22, 2012.

ERWIYONO, R.; PRAWOTO, A. A. Soil nutrient conditions in coffee cultivation with industrial timber plants. Pelita Perkebunan, 24(1):22-34, 2008.

EVIZAL, R. et al. The influence of shade coffee agroecosystem on productivity and farming sustainability. Jurnal Agrotropika, 15(1):17-22, 2010.

EVIZAL, R. et al. The role of shade trees in determining coffee yield. Jurnal Agrotropika, 17(1):19-23, 2012.

HIFNALISA, D.; KARIM, A. Preliminary study of Arabica coffee varieties based on elevation in the Gayo Highlands. Jurnal Agrista, 1:162-172, 2008.

IZZATI, R. et al. Analysis of taste quality of coffea Arabica L. in several altitudes at gayo lues district. International Journal Advanced Research (IJAR), 7(6):461-468, 2019.

KARIM, A.; SUDARSONO, A. I. Nutrient balance of organic Arabica coffee gardens in Central Aceh. Jurnal Agrista, 3(3):201-208, 1999a.

KARIM, A.; WIRADISASTRA, U. S.; SUDARSONO, A. I. Evaluation of land suitability criteria for organic Arbika coffee on Andisols in Central Aceh. Jurnal Agrista, 3(3):191-200, 1999b.

KARIM, A. et al. Land arrangement for citronella (Cymbopogon nardus) and Arabica coffea in the cultivation area ini Gayo Lues District, Aceh Province, Indonesia: A land suitability approach. Aceh International Journal of Science and Technologi, 9(3):207-215, 2020.

KHASANAH, N.; LUSIANA, B.; VAN NOORDWIJK, F. D. M. Simulation of surface runoff and soil loss at various ages of coffee plantations: A case study in Sumberjaya, West Lampung. Agrivita, 26(1):81-89, 2004.

LIN, B. B. Microclimate effects on floweringsuccess in coffee agroforestry systems. American-Eurasian Journal of Agricultural and Environmental Sciences, 3(2):148-152, 2008. 
LISNAWATI1, A. et al. Agroforestry system biodiversity of Arabica coffee cultivation in North Toraja District, South Sulawesi, Indonesia. Biodiversitas, 18(2):741-751, 2017.

MARBUN, P. et al. The classification, characteristics, and assessment of soil profile fertility on Coffea arabica productivity in North Sumatra. Bulgarian Journal of Agricultural Science, 26(3):622-632, 2020.

MUSCHLER, R. G. Shade improves coffee quality in a sub-optimal coffee zone of Costa Rica. Agroforestry Systems, 52:253, 2001.

PEETERS, L. Y. K. et al. Coffee production, timber, and firewood in traditional and Inga-shadedplantation in Southern Mexico. Agriculture, Ecosystems \& Environment, 95(2-3):481-493, 2003.

PIATO, K. et al. Effects of shade trees on robusta coffee growth, yield and quality: A meta-analysis (article). Agronomy for Sustainable Development, 40(38):1-13, 2020.

PIATO, K. at al. Organic farming practices and shade trees reduce pest infestations in Robusta coffea systems in Amazonia (article). Life, 11(413):1-14, 2021.

PRAWOTO, A. A. Coffee yields and mineral cycle in intercropping of Coffea canephora and some species of timber shade trees. Pelita Perkebunan, 24(1):1-21, 2008.

RODRIGUES, W. N. et al. Coffee pruning: Importance of diversity among genotypes of coffea Arabica. African Journal of Agricultural Research, 12(10):850-855, 2017.

SCHALLER, M. et al. Species and site characteristics that permit the association of past-growing trees with crops: The case of Eucalyptus degluptaas coffee shade in Costa Rica. Forest Ecology and Management, 175:206-215, 2003.
SIAHAAN, A. S. A. et al. The growth and yield of coffee Arabica in shade conditions on different treatment of pruning and fertilizing. Russian Journal of Agriculture and Socio-Economic Sciences, 3(99):40-46, 2020.

SILES, P.; HARMAND, J.; VAAST, P. Effects of inga densiflora on the microclimate of Arabica coffee (Coffea arabica L.) and overall biomass under optimal growing conditions in Costa Rica. Agroforestry Systems, 78:269286, 2010.

SOMPORN, C. et al. Effect of shading on yield, sugar content, phenolic acids and antioxidant property of Arabica coffee beans (Coffea Arabica L. cv. Catimor) harvested from north-eastern Thailand. Journal of the Science of Food and Agriculture, 92(9):1956-1963, 2012.

VAAST, P. et al. Fruit thinning and shade improve bean characteristics and beverage quality of Arabica coffee (Coffea arabica L.) under optimal conditions. Journal of the Science of Food and Agriculture, 86(2):197-204, 2006.

VAAST, P. et al. Fruit load and ring-barking affect carbon allocation and photosynthesis of leaf and fruit of Coffea arabica in the field. Tree Physiology, 25(6):753-760, 2005.

VALLADARES F, E. et al. Low leaf level response to light and nutrients in Mediterranean evergreen oaks: A conservative resource-use strategy? New Phytologist, 148(1):79-91, 2000.

WAHYUNI, E.; KARIM, A.; ANHAR, A. Analysis of the taste of organic Arabica coffee at several altitudes and how to process in Gayo high land. Jurnal Manajemen Sumberdaya Lahan, 2(3):261-269, 2013. 